\title{
Clinical and haemodynamic evaluation of mounted porcine heterograft in mitral position
}

\author{
L. COTTER ${ }^{1}$ AND HUGH C. MILLER \\ From the Department of Cardiology, Royal Infirmary of Edinburgh, Edinburgh
}

SUMmaRY Clinical and haemodynamic assessment has been made of 24 patients with porcine heterograft mitral valve replacements. Twenty patients had a good clinical result and were studied electively and 4 patients had persistent symptoms caused either by poor left ventricular function, aortic paraprosthetic regurgitation, mitral paraprosthetic regurgitation, or impaired left ventricular function with a rather small mitral valve area of $1.4 \mathrm{~cm}^{2}$. The mean left ventricular end-diastolic pressure was $17 \cdot 8 \pm$ $1.2 \mathrm{mmHg}$ and the mean mitral valve diastolic gradient was $5.9 \pm 1.0 \mathrm{mmHg}$. The larger prostheses had the smaller gradients. The average mitral valve area was $3.2 \mathrm{~cm}^{2}$ for $35 \mathrm{~mm}$ valves, $2.8 \mathrm{~cm}^{2}$ for $33 \mathrm{~mm}$ valves, $2.1 \mathrm{~cm}^{2}$ for $31 \mathrm{~mm}$ valves, and $2.3 \mathrm{~cm}^{2}$ for $29 \mathrm{~mm}$ valves. Two patients showed significant mitral regurgitation on left ventricular cineangiography but in the remainder the valves were competent.

An apical diastolic murmur was audible in 9 of 24 patients but there was no correlation between the presence of a murmur and the magnitude of the mitral valve gradient or mitral valve area. Nine patients with soft apical systolic murmurs had no evidence of mitral regurgitation but 2 patients with louder murmurs had significant regurgitation.

We conclude that the haemodynamic indices observed with porcine heterograft valves are similar to those observed with other mitral valve prostheses and that though most patients have distinct symptomatic improvement significant haemodynamic abnormalities persist. Apical systolic and diastolic murmurs can be present with normal prosthetic valve function.

Carpentier and Dubost (1972) suggested glutaraldehyde as a method of stabilising porcine aortic valves and Reis and his associates (1971) described the use of a flexible stent on which such valves could be mounted and used as prostheses. These advances were followed by the successful use of mounted porcine heterograft valves in many centres (Brown et al., 1974; Carpentier et al., 1974; Horowitz et al., 1974; Cohn et al., 1975; Johnson et al., 1975; McIntosh et al., 1975; Hannah and Reis, 1976; Sang et al., 1976; Stinson et al., 1977). Their major advantage has been the diminished need for long-term anticoagulation (Cohn et al., 1975; Stinson et al., 1977), while the main disadvantage, as with other tissue valves, has been concern about their long-term durability (Roberts, 1976). As yet few clinical and haemodynamic studies of these valves have been available. This report concerns the appraisal of a group of

'Present address: Cerdiac Department, Brompton Hospital, Fulham Road, London SW3.

Received for publication 1 June 1978 patients in whom the clinical and haemodynamic function of their implanted mounted porcine heterografts has been assessed. All of the prostheses described in this report were manufactured by Hancock laboratories.

\section{Subjects and methods}

Twenty-four patients were studied 4 to 32 months (mean 14 months) after implantation of a mounted porcine heterograft in the mitral position. In 4 patients postoperative haemodynamic assessment was indicated because of continuing symptoms. The other 20 were restudied electively after giving informed consent.

At cardiac catheterisation simultaneous pulmonary capillary wedge pressure and left ventricular pressure were recorded at the same gain with zero level set at mid chest. Left atrial pressure was recorded in case 24. Pulmonary artery wedge pressures were accepted if the pressure contour was distinctly different from, and the phasic and mean pressure were lower than, those recorded 
from the pulmonary artery. The 8 patients in sinus rhythm had a biphasic pulmonary artery wedge pressure trace. Mean mitral valve gradient was obtained by averaging values for 5 cardiac cycles. Mitral valve area was calculated using the Gorlin formula (Gorlin and Gorlin, 1951). Cardiac output was measured by the Fick principle using measured oxygen uptake and arteriovenous oxygen difference. Left ventricular angiography was performed in the right anterior oblique position. The ejection fraction was measured by the area length method of Greene (Greene et al., 1967), and the competence of the mitral valve was assessed. A proportion of patients had preoperative haemodynamic data which have been tabulated with the postoperative results. Four patients had pre-

Table

\begin{tabular}{|c|c|c|c|c|c|c|c|c|c|c|c|c|c|c|c|c|c|}
\hline $\begin{array}{l}\text { Case } \\
\text { no. }\end{array}$ & $\begin{array}{l}\text { Age } \\
(y)\end{array}$ & Sex & Diagnosis & Rhythm & $\begin{array}{l}H R \\
\text { (beats } \mid \\
\text { min) }\end{array}$ & $\begin{array}{l}M P A \\
(m m H g)\end{array}$ & $\underset{g A W}{P A W}$ & $\begin{array}{c}\text { LVEDP } \\
\text { g) }(m m H g)\end{array}$ & $\begin{array}{l}\text { CI } \\
(l / m i n \\
\text { per } \\
\left.m^{2}\right)\end{array}$ & $\begin{array}{c}M V A \\
n\left(\mathrm{~cm}^{2}\right)\end{array}$ & $A \underset{(m m H g)}{M V G}$ & & $\begin{array}{l}g E F \\
(\%) \\
(\%)\end{array}$ & $\begin{array}{l}\text { Other } \\
\text { procedure }\end{array}$ & $\begin{array}{l}\text { NYHA } \\
\text { re class }\end{array}$ & $\begin{array}{l}\text { A Ang } \\
\text { grap } \\
\text { MR }\end{array}$ & $\begin{array}{l}\text { zio- } \\
A R\end{array}$ \\
\hline 1 & 57 & $\mathbf{F}$ & $\begin{array}{l}\text { RHD } \\
\text { MS MR }\end{array}$ & AF & 82 & 32 & 18 & 18 & NA & NA & 0 & 31 & 53 & - & I & 0 & \\
\hline 2 & 61 & F & $\begin{array}{l}\mathrm{RC} \\
\mathrm{MR}\end{array}$ & NSR & 75 & 36 & 26 & 24 & 3.6 & $3 \cdot 3$ & 7 & 33 & 52 & - & I & 0 & \\
\hline 3 & 69 & M & $\begin{array}{l}\text { RHD } \\
\text { MS MR }\end{array}$ & AF & 53 & 32 & 22 & 21 & $2 \cdot 4$ & 1.7 & 4 & 31 & 63 & TA & I & 0 & \\
\hline 4 & 43 & F & $\begin{array}{l}\text { RHD } \\
\text { MS }\end{array}$ & NSR & 77 & 37 & 30 & 27 & 2.9 & $2 \cdot 1$ & 10 & 29 & 51 & - & I & 0 & \\
\hline 5 & 51 & M & $\begin{array}{l}\text { RHD } \\
\text { MS }\end{array}$ & AF & 50 & 40 & 30 & 25 & $1 \cdot 7$ & - & 0 & 33 & 44 & - & I & 0 & \\
\hline 6 & 54 & M & $\begin{array}{l}\mathrm{RC} \\
\mathrm{MR}\end{array}$ & AF & 70 & 20 & 15 & 16 & 2.0 & 3.6 & 1 & 35 & 73 & - & I & 0 & \\
\hline 7 & 60 & $\mathrm{~F}$ & $\begin{array}{l}\text { RHD } \\
\text { MS MR }\end{array}$ & AF & 75 & 27 & 22 & 20 & 2.0 & $2 \cdot 1$ & 5 & 31 & 73 & - & II & $2 / 3$ & \\
\hline 8 & 58 & $\mathbf{M}$ & $\begin{array}{l}\text { Cleft } \\
\text { MV }\end{array}$ & AF & 51 & 31 & 24 & 23 & 1.4 & $2 \cdot 1$ & 3 & 33 & 10 & - & II & 0 & \\
\hline 9 & 66 & $\mathrm{~F}$ & $\begin{array}{l}\text { IHD } \\
\text { RPM }\end{array}$ & AF & 78 & 32 & 22 & 15 & $3 \cdot 1^{\mathrm{E}}$ & $2 \cdot 6$ & 6 & 31 & 52 & CABG & I & 0 & \\
\hline 10 & 57 & M & $\begin{array}{l}\text { RHD } \\
\text { MS MR }\end{array}$ & AF & 66 & 27 & 19 & 17 & 3.6 & $3 \cdot 1$ & 3 & 35 & 74 & - & II & 0 & \\
\hline 11 & 50 & M & $\begin{array}{l}\text { RHD } \\
\text { AS MPS }\end{array}$ & AF & 77 & 30 & 24 & 20 & $2 \cdot 3$ & 1.6 & 8 & 29 & 49 & AVR & III & 0 & $2 / 3$ \\
\hline 12 & 49 & F & $\begin{array}{l}\text { RHD } \\
\text { MS MR }\end{array}$ & AF & 97 & 36 & 23 & 16 & $2 \cdot 5^{\mathrm{E}}$ & $2 \cdot 0$ & 8 & 31 & 39 & - & I & 0 & \\
\hline 13 & 36 & M & $\begin{array}{l}\text { RHD } \\
\text { MR AR }\end{array}$ & AF & 59 & 30 & 24 & 15 & 3.7 & $2 \cdot 4$ & 15 & 31 & 29 & AVR & III & 0 & 0 \\
\hline 14 & 35 & M & $\begin{array}{l}\text { RHD } \\
\text { MS MR }\end{array}$ & NSR & 71 & 19 & 9 & 8 & $4 \cdot 1$ & 3.5 & 5 & 33 & 50 & - & I & 0 & \\
\hline 15 & 39 & $\mathbf{F}$ & $\begin{array}{l}\text { RHD } \\
\text { MS }\end{array}$ & NSR & 66 & 23 & 15 & 15 & $4 \cdot 0$ & $3 \cdot 3$ & 6 & 29 & 62 & - & I & 0 & \\
\hline 16 & 34 & $\mathrm{~F}$ & $\begin{array}{l}\text { RHD } \\
\text { MS MR }\end{array}$ & NSR & 75 & 23 & 17 & 10 & $5 \cdot 4$ & - & 0 & 33 & 73 & - & I & 0 & \\
\hline 17 & 55 & $\mathbf{M}$ & $\begin{array}{l}\text { RHD } \\
\text { MS }\end{array}$ & $\mathrm{AF}$ & 68 & 22 & 12 & 14 & $2 \cdot 6$ & 1.8 & 4 & 31 & 59 & - & I & 0 & \\
\hline 18 & 54 & $F$ & $\begin{array}{l}\text { RHD } \\
\text { MS MR }\end{array}$ & $\mathrm{AF}$ & 61 & 32 & 23 & 19 & $4 \cdot 1$ & $2 \cdot 1$ & 10 & 31 & 88 & - & I & 0 & \\
\hline 19 & 66 & $\mathbf{M}$ & $\begin{array}{l}\text { RHiD } \\
\text { SBE } \\
\text { AR MR }\end{array}$ & NSR & 72 & 37 & 33 & 25 & $3 \cdot 1$ & $1 \cdot 3$ & 21 & 31 & 61 & - & II & 0 & \\
\hline 20 & 41 & $F$ & $\begin{array}{l}\text { RHD } \\
\text { MR MS AR }\end{array}$ & AF & 61 & 15 & 8 & 8 & 2.5 & $2 \cdot 2$ & 3 & 33 & 63 & - & II & 0 & \\
\hline 21 & 43 & $\mathbf{M}$ & $\begin{array}{l}\text { RHD } \\
\text { MR }\end{array}$ & AF & 69 & 20 & 15 & 14 & 3.7 & $3 \cdot 1$ & 3 & 35 & 58 & - & I & 0 & \\
\hline 22 & 51 & $\mathrm{~F}$ & $\begin{array}{l}\text { RHD } \\
\text { MS }\end{array}$ & NSR & 98 & 35 & 20 & 13 & $3 \cdot 2$ & $1 \cdot 7$ & 10 & 31 & 53 & - & II & 0 & \\
\hline 23 & 59 & $\mathbf{M}$ & $\begin{array}{l}\text { IHD } \\
\text { MR }\end{array}$ & NSR & 120 & 42 & 36 & 30 & $2 \cdot 3$ & 3.0 & 1 & 35 & 10 & CABG & III & 0 & \\
\hline 24 & 36 & $\mathbf{F}$ & $\begin{array}{l}\text { RHD } \\
\text { MPR }\end{array}$ & AF & 115 & 40 & 35 & 15 & $5 \cdot 0$ & $3 \cdot 0$ & 8 & 31 & NA & - & III & $2 / 3$ & \\
\hline $\begin{array}{l}\text { Mean } \\
\pm \text { SEM }\end{array}$ & $\begin{array}{l}51 \\
12 \cdot 1\end{array}$ & & & & $\begin{array}{r}74 \cdot 4 \\
3 \cdot 6\end{array}$ & $\begin{array}{r}29.9 \\
1.5\end{array}$ & $\begin{array}{r}21 \cdot 7 \\
1 \cdot 5\end{array}$ & $\begin{array}{r}17 \cdot 8 \\
1 \cdot 2\end{array}$ & $\begin{array}{l}3 \cdot 1 \\
0 \cdot 21\end{array}$ & $\begin{array}{l}2 \cdot 46 \\
0 \cdot 15\end{array}$ & $\begin{array}{l}5.9 \\
1.0\end{array}$ & & $\begin{array}{r}53.9 \\
3.9\end{array}$ & & & & \\
\hline
\end{tabular}

AF, atrial fibrillation; AR, aortic regurgitation; AS, aortic stenosis; AVR, aortic valve replacement; CABG, coronary artery bypass graft; CI, cardiac index; E, estimated; EF, ejection fraction; HR, heart rate; IHD, ischaemic heart disease; LVEDP, left ventricular end-diastolic pressure; MPA, main pulmonary artery mean pressure; MPR, mitral prosthetic regurgitation; MPS, mitral prosthetic stenosis; MR, mitral regurgitation; MS, mitral stenosis; MV, mitral valve; MVA, mitral valve area; MVG, mitral valve gradient; NA, not available; NSR, normal sinus rhythm; PAW, pulmonary artery wedge mean pressure; RC, ruptured chordae; RHD, rheumatic heart disease; RPM, ruptured papillary muscle; SBE, subacute bacterial endocarditis; SEM, standard error of mean; TA, tricuspid annuloplasty. 

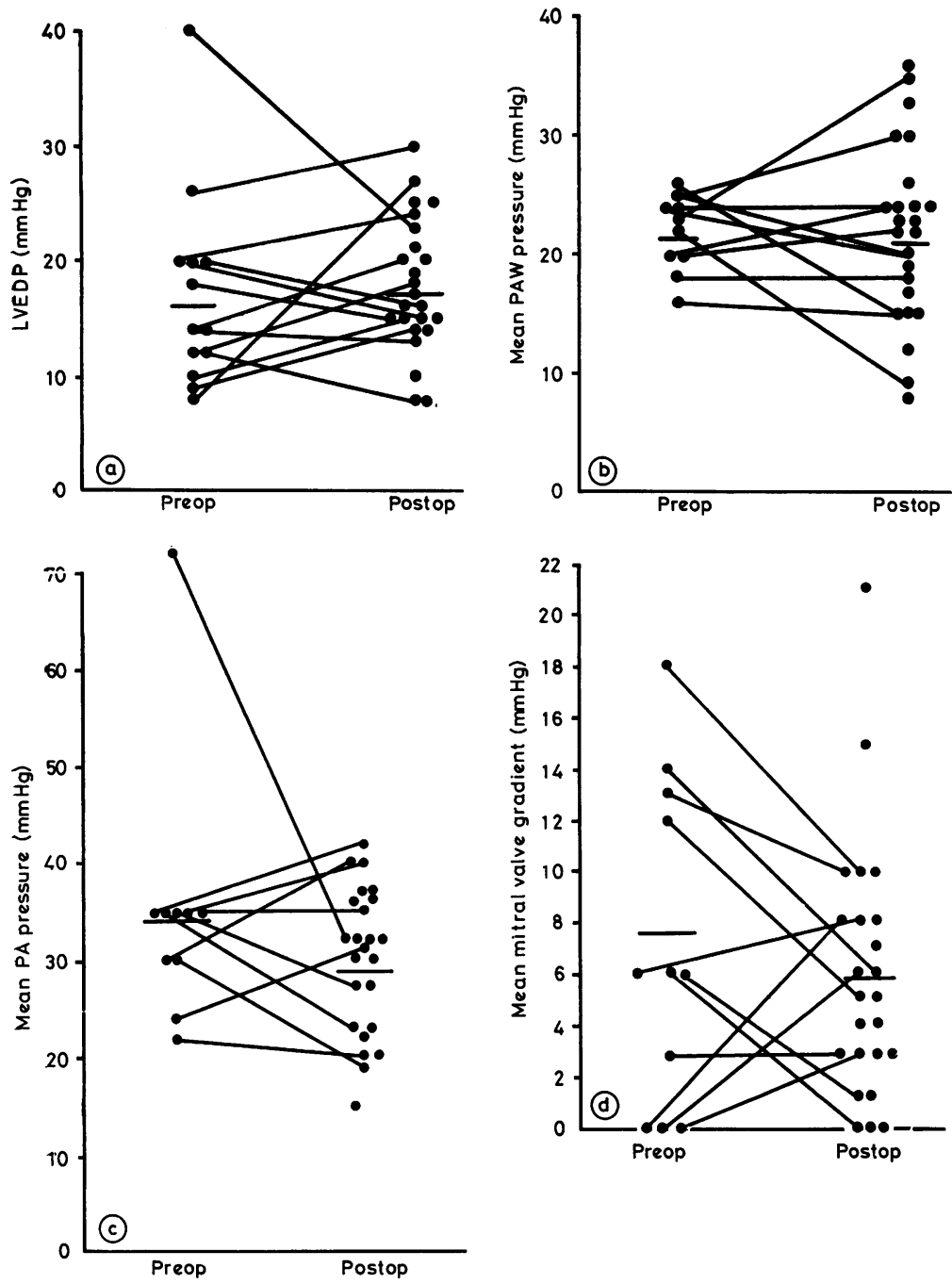

Fig. 1a-1d Preoperative and postoperative haemo-
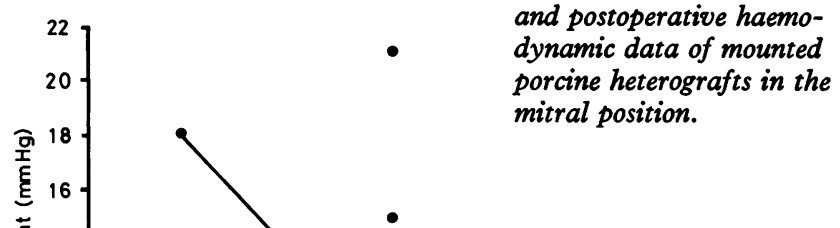
porcine heterografts in the mitral position.

operative coronary angiography which was normal in 2.

\section{Postoperative results}

\section{HAEMODYNAMICS}

Individual values are shown in the Table and Fig. 1 and standard errors of the mean are given in the text.

The mean left ventricular end-diastolic pressure (Fig. 1a) was $17.8 \pm 1.2 \mathrm{mmHg}$ (range 8 to 30 $\mathrm{mmHg}$ ) compared with an almost identical preoperative mean value of $17.2 \pm 2.4 \mathrm{mmHg}$ (range 8 to $40 \mathrm{mmHg}$ ) in the 13 patients in whom these data are available. Seven patients showed a rise in left ventricular end-diastolic pressure and in 7 the postoperative values fell. Mean pulmonary artery wedge pressures postoperatively (Fig. 1b) averaged $21.7 \pm 1.5 \mathrm{mmHg}$ (range 9 to $36 \mathrm{mmHg}$ ) which is almost identical to the preoperative average of $21.8 \pm 1.0 \mathrm{mmHg}$ (range 16 to 26 $\mathrm{mmHg}$ ). The average mean pulmonary artery pressure postoperatively (Fig. 1c) was $29.9 \pm$ $1.5 \mathrm{mmHg}$ (range 15 to $42 \mathrm{mmHg}$ ) while the average preoperative mean pulmonary artery pressure was $31.2 \pm 1.7 \mathrm{mmHg}$ (range 22 to 72 $\mathrm{mmHg}$ ). The mean mitral diastolic gradient postoperatively averaged $5.9 \mathrm{mmHg}$ (range 0 to $21 \mathrm{mmHg}$ ) (Fig. 1d). The average gradient for the $35 \mathrm{~mm}$ stent mounted valve was $2.0 \mathrm{mmHg}$ (range 1 to $3 \mathrm{mmHg}$ ), for the $33 \mathrm{~mm}$ stent was $3.0 \mathrm{mmHg}$ (range 0 to $7 \mathrm{mmHg}$ ), for the $31 \mathrm{~mm}$ stent was 


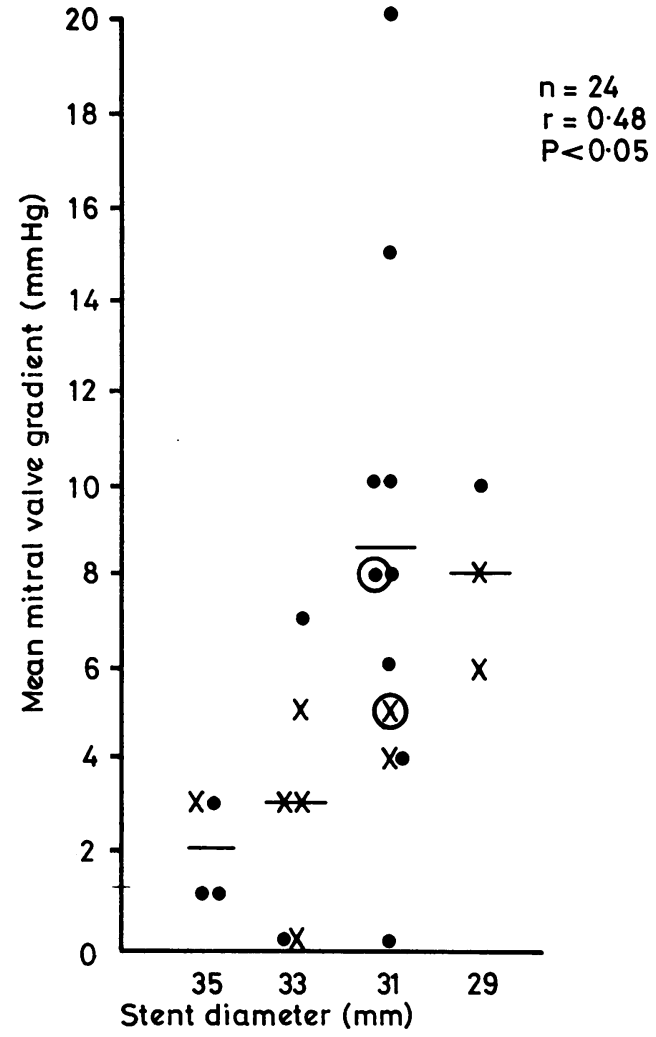

Fig. 2 Mitral valve gradient related to stent diameter. $X$, apical mid-diastolic murmur; $O$, apical pansystolic murmur.

$8.3 \mathrm{mmHg}$ (range 0 to $21 \mathrm{mmHg}$ ), and for the $29 \mathrm{~mm}$ stent was $8.0 \mathrm{mmHg}$ (range 6 to $10 \mathrm{mmHg}$ ). The relation between mitral valve gradient and stent diameter was statistically significant $(r=0.69$, $P<0.05)$ as shown in Fig. 2.

Two patients (cases 9 and 13) were unable to perform expired air collection and an estimated oxygen uptake was used to calculate cardiac output (Robertson and Reid, 1952) and to derive mitral valve area. The cardiac index ranged from 1.4 to $5.41 / \mathrm{min}$ per $\mathrm{m}^{2}$ with an average of $3.1 \pm$ $0.211 / \mathrm{min}$ per $\mathrm{m}^{2}$. The average mitral valve area for 21 patients in whom it could be calculated postoperatively was $2.5 \mathrm{~cm}^{2}$ (range 1.3 to $3.6 \mathrm{~cm}^{2}$ ). The average area for the $35 \mathrm{~mm}$ diameter stent valves was $3.5 \mathrm{~cm}^{2}$ (range 3.0 to $3.6 \mathrm{~cm}^{2}$ ), that for the $33 \mathrm{~mm}$ stents was $2.5 \mathrm{~cm}^{2}$ (range 1.1 to $3.5 \mathrm{~cm}^{2}$ ), that for the $31 \mathrm{~mm}$ stent valves was $2.0 \mathrm{~cm}^{2}$ (range 1.3 to $3.0 \mathrm{~cm}^{2}$ ), while that for the $29 \mathrm{~mm}$ stent valves was $2.2 \mathrm{~cm}^{2}$ (range 1.6 to $3.0 \mathrm{~cm}^{2}$ ). Discounting the patients in whom the area could not be calculated ( 3 patients) the valve area cor- related significantly with the stent diameter $(\mathrm{r}=0.56, \mathrm{P}<0.01)$.

The ejection fraction averaged $53.9 \pm 3.9$ per cent (range 10 to $88 \%$ ). Left ventricular angiography showed important mitral regurgitation in 2 patients but the prosthesis was competent in the remaining 22 patients. Aortography showed important aortic regurgitation in 2 other patients.

\section{Clinical results}

Functional improvement from preoperative class III or IV to functional class I or II was noted in 20 of the 24 patients studied (Fig. 3). Of the 4 patients with a poor clinical result, 1 was found to have important mitral paraprosthetic regurgitation (the mean mitral valve gradient was $8 \mathrm{mmHg}$ ) and another had severe aortic paraprosthetic regurgitation (mean mitral valve gradient $8 \mathrm{mmHg}$ ). A third patient had a mean mitral diastolic gradient of $15 \mathrm{mmHg}$ (valve area $2.4 \mathrm{~cm}^{2}$ ) combined with an ejection fraction of 29 per cent. The fourth patient had severe coronary artery disease and an ejection fraction of 10 per cent with a satisfactory prosthesis.

Clinical examination revealed a grade 1 to 2 out of 6 apical mid-systolic murmur in 9 patients, none of whom had angiographic evidence of mitral regurgitation. Two patients with important mitral paraprosthetic regurgitation had grade 3 out of 6 pansystolic murmurs.

Diastolic murmurs were audible at the apex in 9 of the 24 patients. Seven of the murmurs were grade 1 or 2 out of 6,2 were grade 3 out of 6 . There was no correlation between the stent diameter of the mitral valve implanted or the mitral valve area and the presence of a murmur, nor was there

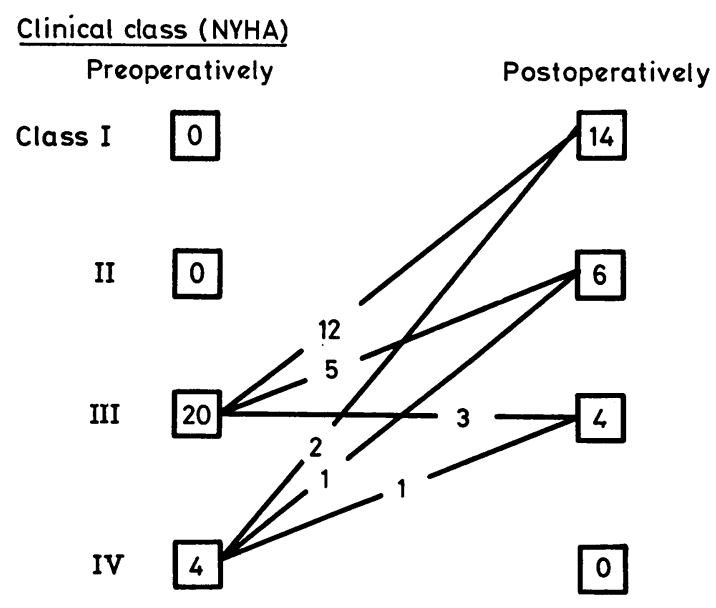

Fig. 3 Clinical class (NYHA) pre-and postoperatively. 


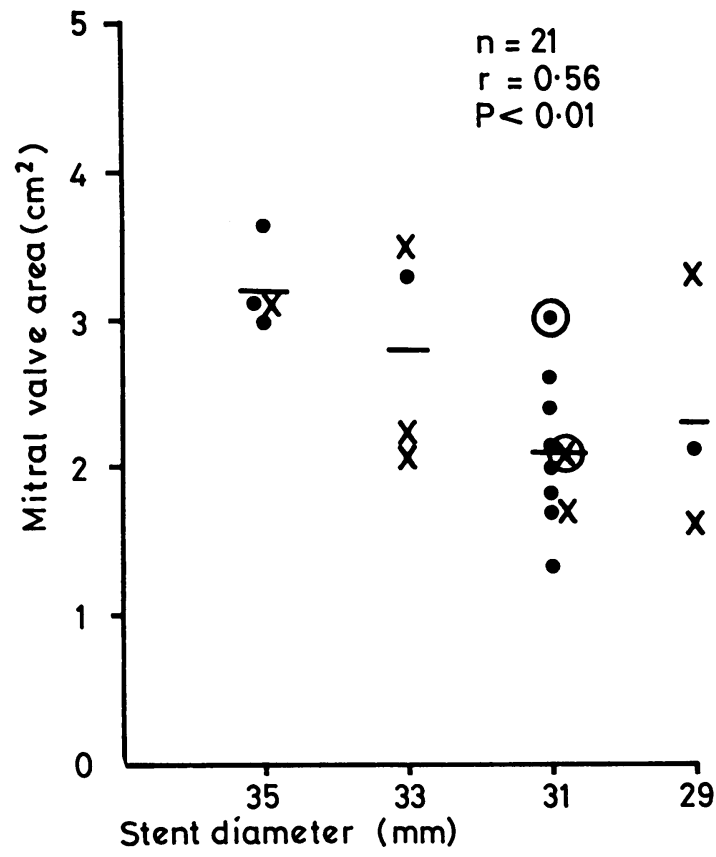

Fig. 4 Mitral valve area related to stent diameter. $X$, apical mid-diastolic murmur; $O$, apical pansystolic murmur.

any correlation between the presence of a murmur and the size or indeed the presence of a mitral diastolic gradient (Fig. 2 and 4).

\section{Discussion}

The majority of patients undergoing mitral valve replacement with a mounted porcine heterograft have a good clinical result (Sang et al., 1976; Stinson et al., 1977). This is also true of other widely used mitral valve prostheses (Winter et al., 1972; Böök, 1974; Brown et al., 1974). The main advantage of the heterograft valve has been the relatively low incidence of thromboembolic complications (Wallace, 1975; Roberts, 1976; Stinson et al., 1977). Our practice has been to anticoagulate our patients for 6 weeks postoperatively and then to stop anticoagulants unless a massive left atrium or atrial thrombus has been found at operation. In this series we have noted no embolic phenomena though we have encountered several major emboli in our total heterograft experience.

The haemodynamic findings in this series are similar to those found by other investigators (Horowitz et al., 1974; Johnson et al., 1975; McIntosh et al., 1975; Hannah and Reis, 1976). Hannah and Reis (1976) found average gradients of $5.2 \mathrm{mmHg}, 2.3 \mathrm{mmHg}, 2.5 \mathrm{mmHg}$, and 2.7
$\mathrm{mmHg}$ across the $29 \mathrm{~mm}, 31 \mathrm{~mm}, 33 \mathrm{~mm}$, and $35 \mathrm{~mm}$ stent diameter prostheses, respectively. Johnson and his colleagues (1975) found an average gradient of $5.5 \mathrm{mmHg}$ in the 14 patients they studied while Brown et al. (1974) and later McIntosh et al. (1975) of the Bethesda group found gradients of up to $15 \mathrm{mmHg}$, but emphasised that many patients had no gradients. No report of a gradient as high as $21 \mathrm{mmHg}$ found in one of our patients has been made previously. The resting cardiac output was $6.8 \mathrm{l} / \mathrm{min}$ and the mitral valve area $1.3 \mathrm{~cm}^{2}$. This is similar to other patients and the large gradient presumably reflects the high resting cardiac output rather than prosthetic valve dysfunction. Postoperatively this patient had a good clinical result, improving from functional class IV to class II and therefore no further intervention has been contemplated. With this one exception the atrioventricular gradients found with the porcine heterografts are similar to those found across the other commonly used prostheses (Winter et al., 1972; Böök, 1974; Brown et al., 1974; Angell et al., 1977; Ionescu et al., 1977).

Many of our patients had abnormally high left ventricular end-diastolic pressure postoperatively, and reduced ejection fractions. These indices of left ventricular dysfunction did not correlate significantly with the total cardiopulmonary bypass time or with the aortic cross clamp time. Deterioration in left ventricular function after mitral valve replacement has been well documented previously (Hultgren et al., 1968; Gold, 1974; Maloney et al., 1975) but is not fully understood though it may be related to the bypass technique. In this series myocardial preservation with local hypothermia using ice-cold saline was the technique employed. It is striking that in spite of the frequency of significant haemodynamic abnormalities postoperatively, both in terms of left ventricular and valve function, the majority of patients have such obvious symptomatic improvement. This discrepancy between clinical and haemodynamic results is not an infrequenc finding after mitral valve surgery, and an abnormality of left ventricular compliance has been suggested as an explanation for the increased left ventricular end-diastolic pressures sometimes encountered (Feigenbaum et al., 1968). Recently Sutton et al. (1977) have mentioned several patients with small or absent mitral valve gradients in whom symptoms were relieved by mitral valve surgery. They postulate that removal of the subvalve apparatus is responsible for the improvement and this may be a factor in our cases also.

The presence of systolic murmurs in patients with normally functioning mitral porcine hetero- 
grafts and no other valvular disease was noted by Horowitz and his colleagues (1974) in 11 of 14 patients. One patient had a mid-diastolic murmur and he had a pannus of tissue interfering with the function of an otherwise normal heterograft, effectively causing mitral prosthetic obstruction. Nine of our patients had systolic murmurs similar to those described by Horowitz et al., with no evidence of mitral regurgitation. In addition, we found mitral diastolic murmurs in 9 of the 24 patients. These murmurs gave no guide to the severity or presence of a transvalvular gradient. In 2 of the patients it is possible that the diastolic murmur was caused by increased flow associated with concomitant mitral regurgitation. Another patient with a mid-diastolic murmur had mild aortic regurgitation and this may have been an example of the Austin Flint phenomenon, which can occur with mitral prostheses (Epstein and Coulshed, 1975; Schaefer et al., 1975). In the other 6 patients with apical mid-diastolic murmurs, however, no such explanation is available and we conclude that apical systolic and diastolic murmurs may be associated with normal prosthetic valve function.

\section{References}

Angell, W. W., Angell, J. D., and Sywak, A. (1977). Selection of tissue or prosthetic valve: a 5 year prospective, randomised comparison. Fournal of Thoracic and Cardiovascular Surgery, 73, 43-53.

Böök, K. (1974). Mitral valve replacement with the tilting disc valve-clinical and haemodynamic studies in isolated mitral valve lesions. Scandinavian Fournal of Thoracic and Cardiovascular Surgery, Suppl. 12, 1-28.

Brown, J. W., Myerowitz, P. D., Cann, M. S., Colvin, S. B., McIntosh, C. L., and Morrow, A. G. (1974). Clinical and hemodynamic comparisons of Kay-Shiley, Starr-Edwards No. 6520, and Reis-Hancock porcine xenograft mitral valves. Surgery, 76, 983-991.

Carpentier, A., Deloche, A., Relland, J., Fabiani, J. N., Forman, J., Camilleri, J. P., Soyer, R., and Dubost, C. (1974). Six year follow up of glutaraldehyde preserved heterografts. Fournal of Thoracic and Cardiovascular Surgery, 68, 771-782.

Carpentier, A., and Dubost, G. (1972). From xenograft to bioprosthesis: evolution of concepts and techniques of valvular xenografts. In Biological Tissue in Heart Valve Replacement, p. 515, ed M. I. Ionescu, D. N. Ross, and G. H. Wooler. Butterworth, London.

Cohn, L. H., Lambert, J. J., Castaneda, A. R., and Collins, J. J., Jr. (1975). Cardiac valve replacement with the stabilised glutaraldehyde porcine aortic valve: indications, operative results and follow up. Chest, 68, 162-165.

Epstein, E. J., and Coulshed, N. (1975). Murmurs and prostheses (correspondence). Circulation, 52, 965.

Feigenbaum, H., Linback, R. E., and Nasser, W. K. (1968), Hemodynamic studies before and after instrumental mitral commissurotomy. Circulation, 38, 261-276.

Gold, R. G. (1974). Deterioration in left ventricular function after mitral valve replacement (abstract). British Heart fournal, 36, 1038-1039.

Gnorla, R., and Gorlin, S. G. (1951). Hydraulic formula for calculation of the area of the stenotic mitral valve, other cardiac valves and central circulatory shunts. American Heart fournal, 41, 1-29.

Greene, D. G., Carlisle, R., Grant, G., and Bunnel, I. L. (1967). Estimation of left ventricular volume by one plane cineangiography. Circulation, 35, 61-69.

Hannah, H., III, and Reis, R. L. (1976). Current status of porcine heterograft prostheses : a 5 year appraisal. Circulation, 54, Suppl. III, 3-27.

Horowitz, M. S., Goodman, D. J., Fogarty, T. J., and Harrison, D. C. (1974). Mitral valve replacement with the glutaraldehyde-preserved porcine heterograft: clinical, hemodynamic and pathological considerations. Fournal of Thoracic and Cardiovascular Surgery, 67, 885-895.

Hultgren, H., Hubis, H., and Shumway, N. (1968). Cardiac function following mitral valve replacement. American Heart fournal, 75, 302-312.

Ionescu, M. I., Tandon, A. P., Mary, D. A. S., and Abid, A. (1977). Heart valve replacement with the Ionescu-Shiley pericardial xenograft. Fournal of Thoracic and Cardiovascular Surgery, 73, 31-41.

Johnson, A. D., Daily, P. O., Peterson, K. L., Le Winter, M., DiDonna, G. J., Blaire, G., and Niwayama, G. (1975). Functional evaluation of the porcine heterograft in the mitral position. Circulation, 51 and 52, Suppl. I, 40-48.

McIntosh, C. L., Michaelis, L. L., Morrow, A. G., Itscoitz, S. B., Redwood, D. R., and Epstein, S. E. (1975). Atrioventricular valve replacement with the Hancock porcine xenograft: a 5 year clinical experience. Surgery, 78, 768-775.

Maloney, J. V., Jr., Cooper, N., Mulder, D. G., and Buckberg, G. D. (1975). Depressed cardiac function after mitral valve replacement: problem of myocardial preservation during operation. Circulation, 51 and 52, Suppl. I, 3-8.

Reis, R. L., Hancock, W. D., Yarbrough, J. W., Glancy, D. L., and Morrow, A. G. (1971). The flexible stent: a new concept in the fabrication of tissue heart valve prostheses. Fournal of Thoracic and Cardiovascular Surgery, 62, 683-689.

Roberts, W. C. (1976). Choosing a substitute cardiac valve: type, size, surgeon. American fournal of Cardiology, 38, 633-644.

Robertson, J. D., and Reid, D. D. (1952). Standards for the basal metabolism of normal people in Britain. Lancet, 1, 940-943.

Sang, C., Caves, P. K., Davidson, K. G., Miller, H. C., and Kitchin, A. H. (1976). Initial clinical experience with a stented porcine aortic valve xenograft (abstract). British Heart Fournal, 38, 875-876.

Schaefer, R. A., McAnulty, J. H., Starr, A., and Rahimtoola, S. H. (1975). Diastolic murmurs in the presence of StarrEdwards mitral prosthesis, with emphasis on the genesis of the Austin Flint murmur. Circulation, 51, 402-409.

Stinson, E. B., Griepp, R. B., Oyer, P. E., and Shumway, N. E. (1977). Long-term experience with porcine aortic valve xenografts. Fournal of Thoracic and Cardiovascular Surgery, 73, 54-63.

Sutton, M. G. St. J., Traill, T. A., Ghafour, A. S., Brown, D. J., and Gibson, D. G. (1977). Echocardiographic assessment of left ventricular filling after mitral valve surgery. British Heart fournal, 39, 1283-1291.

Wallace, R. B. (1975). Tissue valves. American fournal of Cardiology, 35, 866-871.

Winter, T. Q., Reis, R. L., Glancy, D. L., Roberts, W. C., Epstein, S. E., and Morrow, A. G. (1972). Current status of the Starr-Edwards cloth-covered prosthetic cardiac valves. Circulation, 45 and 46, Suppl. I, 14-24.

Requests for reprints to Dr Hugh C. Miller, Department of Cardiology, Royal Infirmary of Edinburgh, Lauriston Place, Edinburgh EH3 9YW. 